\title{
The Usefulness of the Yantras: Some Historical and Cultural Perspectives
}

\author{
Paulo Nuno Martins* \\ CTEC - Fernando Pessoa University of Oporto, CIUHCT - New University of Lisbon
}

*Corresponding Author: Paulo Nuno Martins, CTEC - Fernando Pessoa University of Oporto, CIUHCT - New University of Lisbon. E-mail: paulonunom@gmail.com.

\begin{abstract}
Yantra is an Indian Sacred artefact that might help an observer to transcend the dualism of the physical world described both in Indian art through the Rasa and science through the Principle of Complementarity of Quantum Mechanics. Thus, the artist and/or engineer and the object created (whether it be a work of art or science) are interconnected through the "conscious mind". This essay aims to highlight some historical and cultural usefulness of the Yantras(Indian sacred artefacts) to people who want to expand their perception of its reality. Nowadays, due to their importance, there is an attempt to draw them through computational artarea (contemporary technology), under the "human-centered computing" category with emphasis on "visualization" and "interaction design".
\end{abstract}

Key words: Rasa (contradictory feelings of an aesthetic experience), Principle of Complementarity of Quantum Mechanics, Yantra (Indian Sacred Artefact), Computational art.

\section{INTRODUCTION}

The Indian Art [1] has had several cultural and religious influences with different philosophical perspectives through the ages [2]. In this regard, the concept Rasa (from the sanskrit "essence" or "feeling of an aesthetic experience") proposed by the Indian sage Bharata Muni [3] is described as a mental, emotional and physical state experienced by the subject or observer in the perception of a work of art, such as painting or poetry. This sage proposed eight states of perception, with ever greater refinement, namely Raudram (from sanskrit "fury"), Bhayānakam (from sanskrit "horror"), Bibhatsam (from sanskrit "aversion, repulsion"), Sringara (from sanskrit "love, attraction"), Viram (from sanskrit "courage"), Kārunyam (from sanskrit"compassion"), Hāsyam (from sanskrit "laughter, joy"), Adbhutam (from sanskrit "wonder"). Subsequently, the philosopher Abhinavagupta [4] complemented this term with other Rasas, namely Vătsalya (from the sanskrit "love of the parents"), Sāntam (from the sanskrit "peace") and Bhakti (from sanskrit "devotion to God"). This Theory of Art and Aesthetics highlights the role of the observer's consciousness in the experience of a work of art. Nowadays, Rasa findings are seen in other fields of knowledge, such as, science [5]. It is known from the Principle of Complementarity of Quantum Mechanics that a quantum particle can be described as a "wave of probability" which is both "wave" and "particle" (in "potentia") that comes true when an observation is made by an observer. It is the "conscious mind" of the observer who decides the aspect of reality he/she wants to observe. The paradox of having two contradictory situations happens, if we consider just a single level of reality - the physical. In this case, as in the Rasa, the observer can see the "wave" or the "particle" aspect of the "wave of probability" in an exclusively way, like the exclusive states of consciousness of love or repulsion, horror or wonder in Rasas.In fact, the paradox disappears if we consider several levels of complexity and reality through a transdisciplinary approach known as "Hidden Third" [6]. Some epistemological interpretation of Quantum Mechanics argues that the "conscious mind" of the observer/subject or artist/engineer is interconnected with the observed object (the artistic or scientific work) that triggers the "aesthetic experience".Thus, the observed object is the manifestation of the "conscious mind" of the artist and/or engineer expressed through her/his thoughts, emotions/feelings and words [7].

\section{METHODS}

In this essay on Indian sacred artefacts, the main scientific articles and books were collected and analyzed, in this area of research, that are available in libraries. Thus, 24 most important items were 
selected, based on the "impact factor" of the article and the "reference" books on this issue. This is to make them useful to the reader who wants to have a global idea of this topic, without neglecting its scientific aspect.

\section{RESULTS AND DISCUSSION}

This section presents the most relevant results obtained from the research work on Indian Sacred artefacts.

\subsection{The Indian Sacred Artefacts: An essay}

We create our own reality through our conscious and unconscious sides. Jung named the patterns of our thoughts, feelings and words existing in our psyche as "archetypes" which are "projected" into the physical world through empirical experiences[8].

In this regard, the sacred artefacts named Yantras have been used in several ways in India since time immemorial [9]. They are a kind of "antenna or command" that allows the connection of the macrocosm (the Universal holographic mind) with the microcosm (the human body) in order to tune in to our deepest potential (our mission or "dharma") on Earth. The activation of eachYantra is done through the visualization of these sacred artefacts, which can be used complementarily with the vocalization of some sacred mantra, such as the sacred Gayatri mantra [10]. The Yantra is an Indian sacred symbol that became known in Western culture through the works of Arthur Avalon (pseudonym of Sir John Woodroffe) and Henrich Zimmer [11]. The Yantra(from sanskrit "support" or " instrument") is a sacred physical instrument with psychosomatic effect. Its main objective is to "tune" the "conscious mind" of the observer (composed by archetypal patterns) with a certain Divine entity 3-D, such as the Divine Mother Durga manifested in some Darshan (from sanskrit "see the Divine") [12].Thus, according to the Divine Entity (and the specific Darshan), we could have different kinds of Yantras for different purposes on Earth. In fact, this important Indian sacred symbol is connected with the spiritual archetype (the Indian deities) within us, and is related with mantras and rituals in order to help the individual to return to original wholeness [13].One of the earliest known pictures is the Sri Yantra[14] that is found in the religious institution named by "Shrungeri Matha"(from sanskrit "shrunga" highest, peak and "geri" hill); it was established by the philosopher Shânkara and is represented in Figure 1.

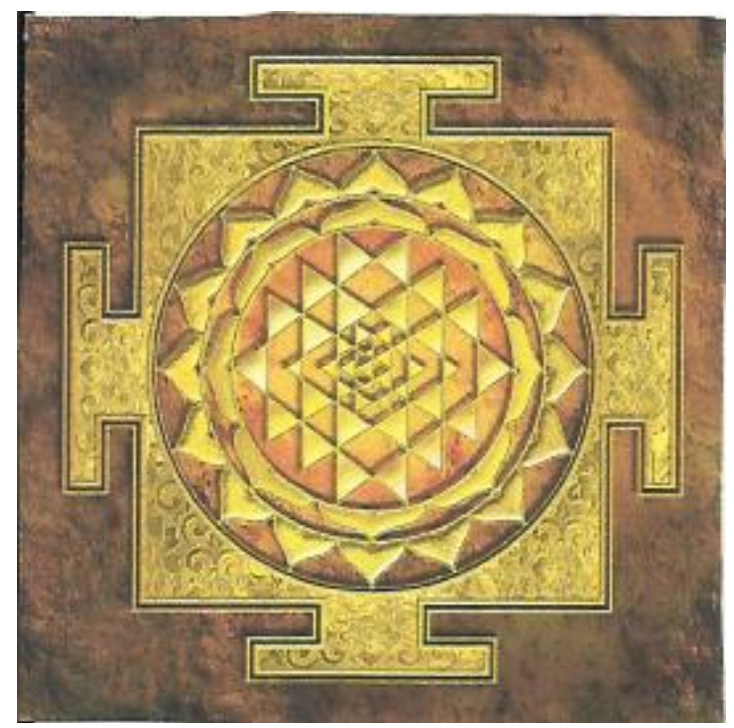

Figure1. Sri Yantra Golden Stone

Photo Source: Courtesy of Lila Sravani (Fine Art America)

This is the most important Yantra [15] and is composed of geometrical shapes, such as dot, lines, triangles, squares, circles and lotus that draw a 2-D fractal pattern of great beauty. For example, the dot (named by bindu) represents the initial sacred Word - the OM -which is the matter in "potentia". The triangle (named by trokona) could point down (which is a symbol of Shakti) and represents the feminine aspect of Creation, while the triangle pointing up (which is a symbol of Shiva) represents the masculine aspect of Creation. Then, the six-pointed star (named by shatkona) represents the union of feminine/matter and masculine/spirit that leads to the manifestation of all forms of creation. The circle 
(named by chakra) represents the spiritual evolution of the "conscious mind", while the square (named by bhupura) represents the physical manifestation of the "conscious mind" on Earth. The lotus (named by padma) represents the real Self or soul.

Sri (chakra)Yantra could contribute to activate the Sahasrara chakra related to connection of the soul with the personality (thoughts, feelings, words) of human beings[16].However, some philosophical and religious perspectives have emphasized that the riches of this world are incompatible with spiritual "treasures". This dualistic conception, between these two ways of life(to life exclusively in the profane world or to be in a total seclusion in a monastery) could be transcended through the help of Yantra. In fact, finding a simultaneous well-being between these two realities is something that has been proposed for more than 5000 years by Ayurveda - traditional Indian medicine - which argues that the health of an individual is achieved by the balance between his mind, body and environment [17]. The key to achieving this goal is accomplished through the awakening of Divine power within us (the Shakti) that is dormant in the Muladhara chakra, as described by the spiritual and philosophical principles of Tantra(from sanskrit "tan" to spread and "tra" instrument) [18], [19]. So, one main purpose of Yantrais to transcend the dualism of the physical world described in art, by the Rasa, and in science, by the Principle of Complementarity, in order to manifest our soul's mission on Earth [20].

Furthermore, the Yantra has several other applications in other areas of human life, such as helping to harmonize the home or workplace, through appropriate architectural alignment that might benefit the habitant or worker, as proposed by the VastuYantra [21].

\section{CONClusions}

This essay sought to highlight the historical and cultural studies of the theme onYantra that were performed through the ages. Yantra is considered to have been divinely revealed to Indian sages who have challenged some mathematicians in the building of figures of such complexity. In fact, the research works of Stefan and J. Hollos[22] have tried to generate computational patterns with an infinite variety of images process (dot, lines, triangles, circles, squares) throughthe ACM Computing Classification System (CCS), in the category "human-centered computing", and"visualization and interaction design".Furthermore, the conceptualization, design and computational implementation of Alexey Kulachev work [23] sought to solve Yantras complexity by looking for mathematical models for the design of the "stars" (union of upward and downward triangles) of Sri Yantra. However, this researcher has suggested that a deeper study of this sacred Indian symbol (consisting of several polygons composed of the intersection of many triangles) is required in the future because it demands the cooperation of experts from different areas of knowledge, such as mathematicians, engineers, historians, psychologists, artistsin order to solve a large number of conceptions and calculations that current computers are not able to perform accurately.

However, the main purpose of this essay was to highlight some historical and cultural perspectives of the essence of the "sacred instrument" designated by Yantra that is achieved not only by scientific and technological progression, but also through the change of paradigm in the values of human being in order to manifest some Divine qualities on Earth, such as love, abundance, happiness and well-being with others [24].

\section{ACKNOWLEDGEMENTS}

The author of this essay wants to acknowledge Mrs. Lila Sravani for authorizing the use of the photo in Figure 1 designated by "Sri Yantra Gold Stone" from Fine Art America.

\section{REFERENCES}

[1] Martins, A. (2018). A Concise History of Indian Sacred Art: Some Philosophical Considerations. International Journal of History and Cultural Studies, 4(3): 19-25.

[2] Dasgupta, S. (1997). A History of Indian philosophy. New Delhi, ND: Motilal Banarsidass. 5 vol.

[3] Ghosh, M. (2002). Natyasastra. New Delhi, ND: Sanctum Books.

[4] Bharati, A.(2006). Abhinavabharati.Delhi: New Bharatiya Book Corporation.

[5] Ede, S. (2008). Art\&Science. London: I.B. Tauris.

[6] Nicolescu, B. (2016). The Hidden Third. New York, NY: Quantum Prose Books. 
[7] Martins, P. (2020). Uma perspectiva transdisciplinar sobre a Ciência, Psicologia e Espiritualidade. Religião, Espiritualidade e Qualidade de Vida,In: Brissos-Lino, J. and Gonzalez, B. (Org.). Edições Universitárias Lusófonas, 2:57-64.

[8] Jung, C.(1947). On the Nature of the Psyche. London: Ark Paperbacks.

[9] Khanna, M. (1981). Yantra. London: Thames\&Hudson.

[10] Vallyon, I. (2020). The Gayatri Mantra. Hamilton, WKO: Sounding - Light Publishing.

[11] Zimmer, H. (1989). Kunst und Yoga imIndischenKultbild. Berlin: Suhrkamp Verlag KG.

[12] Bunce, F. (2006). Yantras of Deities and their numerological foundations: an Iconographic consideration. New Delhi, ND: D.K. Printworld P Ltd.

[13] Bühnemann, G. (2003). Mandalas and Yantras in the Hindu Traditions. Leiden: Brill Publishers.

[14] Bolton, N. andNicol, D. and Macleod, G. (1977). The Geometry of SriYantra, Religion, 7(1): 66-85.

[15] Khanna, M. (2003). Yantra: The Tantric Symbol of Cosmic Unity. Rochester, VT: Inner Traditions.

[16] Rashinkar, V. (2019). Sri Chakra Yantra. Chennai, TN: Notion Press.

[17] Martins, P. (2021). A História e a Filosofia do Ayurveda. Aplicação prática à Índia Portuguesa (século XVIII). Centro de Estudos Indianos, Faculdade de Letras da Universidade de Lisboa. 3 de Março de 2021. URI: https://www.letras.ulisboa.pt/pt/component/ohanah/palestra-a-historia-e-a-filosofia-do-ayurvedaaplicacao-pratica-a-india-portuguesa-seculo-xviii?Itemid=.

[18] Pott, P. (1966). Yoga and Tantra. Leiden: Martinus Nijhoff Publishers.

[19] Tigunait, P. (2007). Tantra Unveiled. Honesdale, PA: Himalayan Institute Press.

[20] Ghose, A. and Alfassa, M. (1990). Psychic Being (Soul: Its Nature, Mission, Evolution). Detroit, MI: Broadside Lotus Press.

[21] Sthapati, V. (2000). VaasuPurusha Mandala. Chennai, TN: Dakshinaa Publishing House.

[22] Hollos, S.;Hollos, J. (2013). Pattern Generation for Computational Art. Longmont, CO: Abrazol Publishing.

[23] Kulachev, A. (1984). SriYantra and its Mathematical Properties, Indian Journal of History of Science, 19 (3): 279-292.

[24] Martins, P. (2021). O Fim Do Romantismo Lunar- 50 anos depois da chegada do homem à Lua(20 de Julho de 1969). In: Religião e Vida: Labirintos da Existência, Brissos-Lino, J. and Pinto, P. (Eds.). Edições Universitárias Lusófonas(accepted for publication).

\section{AUTHORS' BIOGRAPHY}

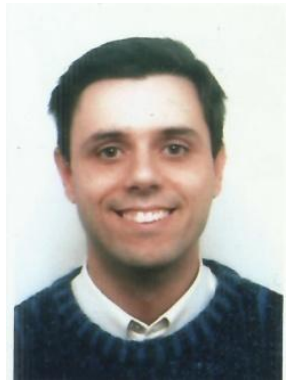

Paulo Nuno Martins, is a Chemical Engineer (Instituto Superior Técnico, University of Lisbon) and $\mathrm{PhD}$ in History and Philosophy of Science, specialization in Epistemology of Science (Faculdade de Ciências e Tecnologia, New University of Lisbon). He has studied for 4 years Eastern languages and culture (Japanese, Chinese) and he is currently a researcher at Interuniversity Center for History of Science and Technology, New University of Lisbon (CIUHCT-UNL) and TransdisciplinaryCenter for Consciousness Studies, University Fernando Pessoa of Oporto (CTEC-UFP), with ORCID: http://orcid.org/0000-0002-2670-3172. He is a member of CIRET (Centre International de Recherchesetd ÉtudesTrans disciplinaires), Paris.

Citation: Paulo Nuno Martins. "The Usefulness of the Yantras: Some Historical and Cultural Perspectives" International Journal of History and Cultural Studies (IJHCS). vol 7, no. 1, 2021, pp. 16-19. doi: DOI: https://doi.org/ 10.20431/2454-7654.0701002.

Copyright: () 2021 Authors. This is an open-access article distributed under the terms of the Creative Commons Attribution License, which permits unrestricted use, distribution, and reproduction in any medium, provided the original author and source are credited. 